\title{
Climate-induced speleothem radiocarbon variability on Socotra Island from the Last Glacial Maximum to the Younger Dryas
}

\author{
Steffen Therre $^{1}$, Jens Fohlmeister ${ }^{2,3}$, Dominik Fleitmann ${ }^{4}$, Albert Matter ${ }^{5}$, Stephen J. Burns ${ }^{6}$, Jennifer Arps ${ }^{1}$, \\ Andrea Schröder-Ritzrau ${ }^{1}$, Ronny Friedrich ${ }^{7}$, and Norbert Frank ${ }^{1}$ \\ ${ }^{1}$ Institute of Environmental Physics, Heidelberg University, Heidelberg, Germany \\ ${ }^{2}$ Potsdam Institute for Climate Impact Research, Potsdam, Germany \\ ${ }^{3}$ GFZ German Research Centre for Geosciences, Section Climate Dynamics and Landscape Development, Potsdam, Germany \\ ${ }^{4}$ Department of Environmental Sciences, University of Basel, Basel, Switzerland \\ ${ }^{5}$ Institute of Geological Sciences, University of Bern, Bern, Switzerland \\ ${ }^{6}$ Department of Geosciences, University of Massachusetts, Amherst, USA \\ ${ }^{7}$ Curt-Engelhorn-Centre Archaeometry gGmbH, Mannheim, Germany
}

Correspondence: Steffen Therre (stherre@iup.uni-heidelberg.de)

Received: 8 August 2019 - Discussion started: 19 September 2019

Accepted: 3 February 2020 - Published: 28 February 2020

\begin{abstract}
In this study, the dead carbon fraction (DCF) variations in stalagmite M1-5 from Socotra Island in the western Arabian Sea were investigated through a new set of highprecision U-series and radiocarbon $\left({ }^{14} \mathrm{C}\right)$ dates. The data reveal an extreme case of very high and also climate-dependent DCF. For M1-5, an average DCF of 56.2 $\pm 3.4 \%$ is observed between 27 and $18 \mathrm{kyr}$ BP. Such high DCF values indicate a high influence of aged soil organic matter (SOM) and nearly completely closed-system carbonate dissolution conditions. Towards the end of the last glacial period, decreasing $\mathrm{Mg} / \mathrm{Ca}$ ratios suggest an increase in precipitation which caused a marked change in the soil carbon cycling as indicated by sharply decreasing DCF. This is in contrast to the relation of soil infiltration and DCF as seen in stalagmites from temperate zones. For Socotra Island, which is influenced by the East African-Indian monsoon, we propose that more humid conditions and enhanced net infiltration after the Last Glacial Maximum (LGM) led to dense vegetation and thus lowered the DCF by increasing ${ }^{14} \mathrm{CO}_{2}$ input into the soil zone. At the onset of the Younger Dryas (YD) a sudden change in DCF towards much higher, and extremely variable, values is observed. Our study highlights the dramatic variability of soil carbon cycling processes and vegetation feedback on Socotra Island manifested in stalagmite DCF on both longterm trends and sub-centennial timescales, thus providing evidence for climate influence on stalagmite radiocarbon. This
\end{abstract}

is of particular relevance for speleothem studies that aim to reconstruct past atmospheric ${ }^{14} \mathrm{C}$ (e.g., for the purposes of ${ }^{14} \mathrm{C}$ calibration), as these would rely on largely climateindependent soil carbon cycling above the cave.

\section{Introduction}

Radiocarbon $\left({ }^{14} \mathrm{C}\right.$ hereafter $)$ dating has fundamentally changed our knowledge of the timing of events and rates of change in archeological and climate proxy records ever since it was pioneered in the late 1940s (Arnold and Libby, 1949). To provide more accurate data for ${ }^{14} \mathrm{C}$ calibration beyond the tree-ring record, speleothems gained importance as a source of information on atmospheric ${ }^{14} \mathrm{C}$. Stalagmite records from tropical and temperate climate zones overlapping the (floating) tree-ring data (Beck et al., 2001; Hoffmann et al., 2010; Southon et al., 2012) have been included in the most recent comprehensive ${ }^{14} \mathrm{C}$ intercalibration data set IntCal13 (Reimer et al., 2013). Radiocarbon calibration based on speleothems relies on the assumption of a low and constant dead carbon fraction (DCF) in the stalagmite, even though one of the included calibration records showed DCF variation by almost a factor of 2 during the YD (Beck et al., 2001; Hoffmann et al., 2010). A unique speleothem calibration record was recently published by Cheng et al. (2018), 
who presented a continuous atmospheric ${ }^{14} \mathrm{CO}_{2}$ reconstruction from stalagmites with a very low $(<6 \%)$ and constant DCF. They further showed that variations of speleothem ${ }^{14} \mathrm{C}$ at Hulu Cave, China, coincide with floating tree-ring ${ }^{14} \mathrm{C}$ variations, proving that even small decadal-scale carbon cycle changes and atmospheric ${ }^{14} \mathrm{C}$ are captured by stalagmites (Adolphi et al., 2017). However, such a situation is unusual, as significant impacts on DCF can arise from carbonate dissolution or climate and carbon cycle changes. By combining ${ }^{14} \mathrm{C}$ dating and elemental $\mathrm{Mg} / \mathrm{Ca}$ analysis, a connection between precipitation (net infiltration) and stalagmite DCF was observed. Several studies attributed this relation to changes in open- vs. closed-system conditions of limestone dissolution, which controls the contribution of very old host rock carbonate to drip water dissolved inorganic carbon (DIC) (Griffiths et al., 2012; Noronha et al., 2014). In a recent study, DCF values exceeding $50 \%$ in a Holocene stalagmite from Corchia Cave, Italy, have been reported (Bajo et al., 2017). Such high DCF values are above the theoretical limit for closed-system carbonate dissolution systems and were attributed to enhanced host rock dissolution by sulfuric acid. Two studies focusing on the direct influence of decomposing soil organic matter $(\mathrm{SOM})$ on soil $\mathrm{CO}_{2}$ found that aging SOM leads to depleted soil gas ${ }^{14} \mathrm{CO}_{2}$ concentration and consequently higher DCF in the stalagmite calcite (Fohlmeister et al., 2011; Rudzka et al., 2011).

The Arabian Sea and Indian Ocean have been the focus of numerous paleoclimate studies in recent years (DiNezio et al., 2018; Fleitmann et al., 2003, 2007; Shakun et al., 2007), particularly concerning the potential impact of climatic changes in the North Atlantic region on the intensity of the Indian summer monsoon and low-latitude climate conditions. For this study, we selected a speleothem (sample M1-5) from Socotra Island which documents a significant increase in monsoonal rainfall during the B $\emptyset$ lling-Allerød interstadial (Shakun et al., 2007). These findings were recently corroborated by DiNezio et al. (2018), who postulated a unique Indian Ocean climate dipole behavior linked to the monsoon during the last glacial. This dipole pattern, which seems predominantly driven by the exposure of the Sunda and Sahul shelves, causes a marked cooling and reduction in moisture availability in the Arabian Sea, leading to dry conditions in the region around Socotra Island during the last glacial period.

Here we present a study of a stalagmite from Socotra Island, with the aim of investigating changes in the local climate regime across the last deglaciation (Termination I). As the climate shifted towards more humid conditions after the LGM, synchronous changes in vegetation and soil carbon cycling may be expected. Hence, we investigate the temporal evolution of the DCF and hydro-proxies of stalagmite M15 from the LGM to the beginning of the Holocene to study the links between above-cave hydrology and soil carbon cycling. Our study shows that increasing moisture on Socotra Island is associated with decreasing DCF, and it proves that the input of ${ }^{14} \mathrm{CO}_{2}$ into the soil zone through denser vegetation above the cave is the determining factor for soil carbon cycling.

\section{Study location and material}

\subsection{Socotra Island}

Socotra Island is the largest island of the eponymous archipelago of four islands on the western margin of the Arabian Sea. It is situated 230 to $360 \mathrm{~km}$ east of the Horn of Africa (Somalia) and $380 \mathrm{~km}$ south of the Arabian Peninsula (Fig. 1). Socotra Island is approximately $130 \mathrm{~km}$ long and $30 \mathrm{~km}$ wide. Its topography varies from coastal plains in the north and south of the island to elevated plateaus several hundred meters above sea level (m a.s.l.). The innermost part of the island consists of a mountainous area with elevations of up to $1500 \mathrm{~m}$ a.s.l. The archipelago is mainly made up of Precambrian basement rocks that are in part overlain by Cretaceous or Tertiary plateau limestone (Schlüter, 2006). The maritime climate of Socotra Island is under the strong influence of the East African-Indian monsoon system reflected in the biannual migration of the Intertropical Convergence Zone (ITCZ) between its Northern Hemisphere winter position in the southern Indian Ocean and its summer position in the Arabian Sea (Shakun et al., 2007) (Fig. 1a, b). This migration is responsible for the bimodal distribution of precipitation. More than $20 \%$ of total annual rainfall on the island occurs in April and May when the northward-migrating ITCZ crosses the island. The second annual crossing of the ITCZ during October to December accounts for more than $50 \%$ of the annual rainfall (Scholte and De Geest, 2010). Today, total precipitation can be as low as $67 \mathrm{~mm} \mathrm{yr}^{-1}$ near the coastal plains, while more than $500 \mathrm{~mm}$ rainfall can occur in the mountainous areas in the inner island with elevations of more than 1000 m a.s.l. (Scholte and De Geest, 2010).

\subsection{Stalagmite M1-5}

Stalagmite M1-5 was collected from Moomi Cave in 2002, which lies on a limestone plateau (Moomi Plateau, ca. $500 \mathrm{~m}$ a.s.l.) in the eastern part of Socotra Island $\left(12^{\circ} 32^{\prime} 04^{\prime \prime} \mathrm{N}, 54^{\circ} 19^{\prime} 00^{\prime \prime} \mathrm{E}\right.$; Fig. 1c). Moomi Cave is approximately $1 \mathrm{~km}$ long, largely horizontal, and overlain by $\sim 20 \mathrm{~m}$ of bedrock (Burns, 2003). Stalagmite M1-5 is approximately $2.2 \mathrm{~m}$ long and 10 to $15 \mathrm{~cm}$ wide and grew roughly $1 \mathrm{~km}$ from the cave entrance. It was sectioned along its growth axis down to the base (Fig. 2) and polished to make the growth layers more visible (Shakun et al., 2007). On the macroscopic scale, there are significant differences visible in the texture and stratigraphy of the stalagmite. The lower part of the stalagmite from its base to approximately $1.5 \mathrm{~m}$ distance from the top shows distinct changes in layer coloring, and it generally has a larger width of approximately $15 \mathrm{~cm}$. In younger parts, the carbonate is brighter and the width rarely 

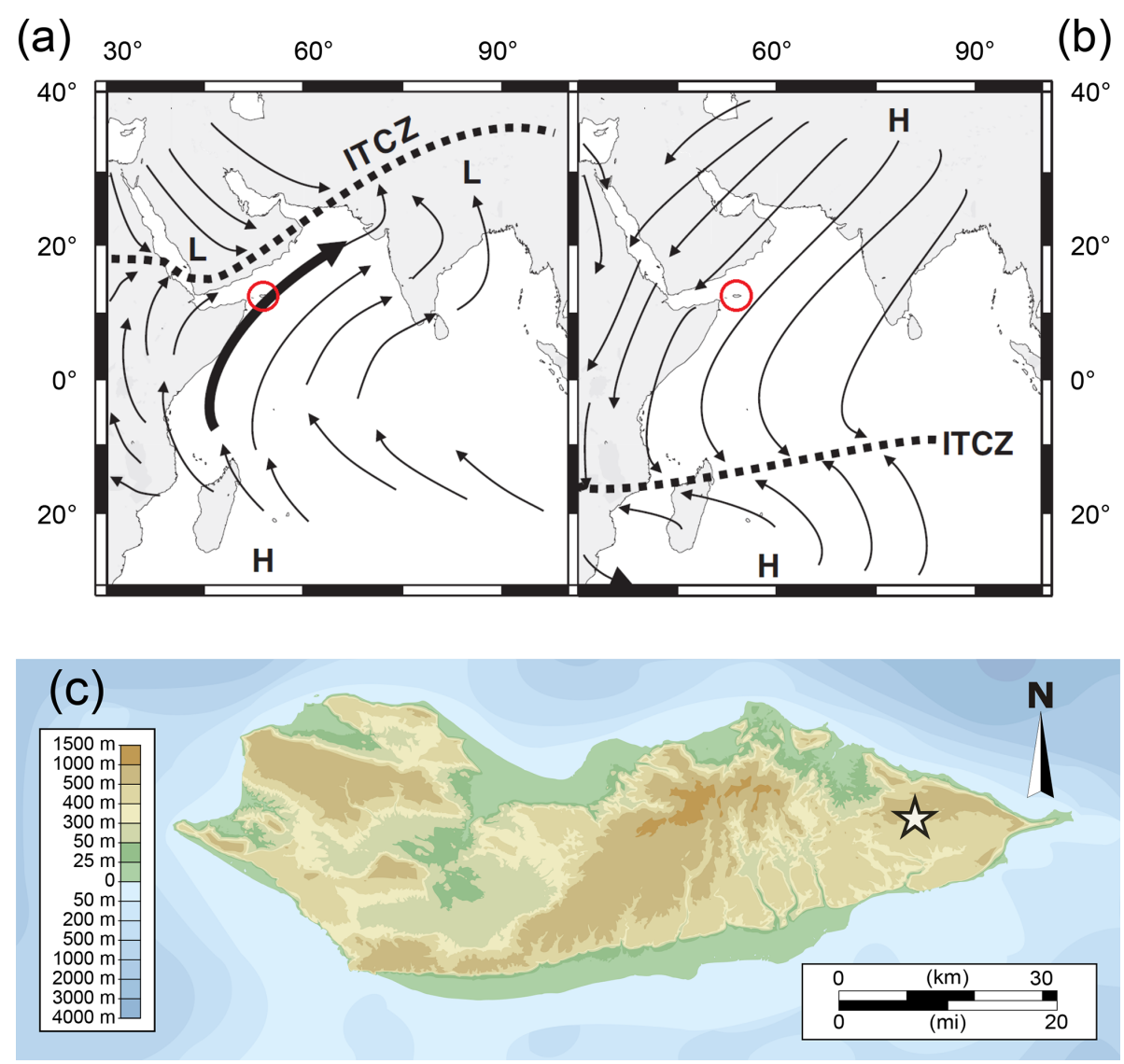

Figure 1. Upper figures show the geographic position of the Socotra archipelago (red circle) in the western Arabian Sea, east of the coast of Somalia with the prevailing monsoonal surface wind patterns in boreal summer (a) and boreal winter (b) relative to the Intertropical Convergence Zone (ITCZ) (graphic adapted from Fleitmann et al., 2007). In a topographic map (c), the position of Moomi Cave in the east of Socotra Island on the Moomi Plateau is indicated by a white star.

exceeds $10 \mathrm{~cm}$. Another visible change can be seen in the uppermost $10 \mathrm{~cm}$ where the layering is much darker, which Shakun et al. (2007) found to occur shortly after an apparent hiatus.

\section{Methods}

\subsection{U-series dating}

Forty samples were analyzed at the Heidelberg Institute of Environmental Physics for this study. M1-5 was previously U-series dated at the Isotope Geology Laboratory, University of Bern. In total, 62 age data points are presently available, in addition to the previous age determination efforts by Shakun et al. (2007). For the sample treatment in Heidelberg, approximately 80 to $120 \mathrm{mg}$ of speleothem calcite were cut with a diamond wire saw or drilled along growth layers. Chemical sample preparation, $\mathrm{U}$ and Th purification, and mass spectrometric measurements follow the procedures described in detail in Arps (2017), Douville et al. (2010), and Wefing et al. (2017). Activity ratios were determined using a Thermo Fisher Neptune Plus multicollector inductively coupled plasma mass spectrometer (MC-ICP-MS) at the Institute of Environmental Physics, Heidelberg University, Germany. Multiple measurements of the HU-1 standard resulted in a value of $1.00002 \pm 0.00082$ for $\left({ }^{234} \mathrm{U} /{ }^{238} \mathrm{U}\right)$ and $1.00004 \pm 0.00082$ for $\left({ }^{230} \mathrm{Th} /{ }^{238} \mathrm{U}\right)$ for 517 samples over 22 months. The HU-1 standards used to bracket the sample measurements accordingly yield a reproducibility of $0.82 \%$ o for $\left({ }^{234} \mathrm{U} /{ }^{238} \mathrm{U}\right)$ and $\left({ }^{230} \mathrm{Th} /{ }^{238} \mathrm{U}\right)$. Full procedural blanks were found to be smaller than $0.04 \mathrm{fg}$ for ${ }^{230} \mathrm{Th}$ and $0.4 \mathrm{fg}$ for ${ }^{234} \mathrm{U}$. The calculations for the radiometric ages were performed using the half-lives from Cheng et al. (2000) to maintain comparability with the record from Shakun et al. (2007). More recent half-life values do not significantly change radiometric age estimates (see Results section). For detrital ${ }^{230} \mathrm{Th}$ correction, a ${ }^{232} \mathrm{Th} /{ }^{238} \mathrm{U}$ weight ratio of $3.8 \pm 1.9$ and secular radioactive equilibrium within the uranium decay chain was assumed. 


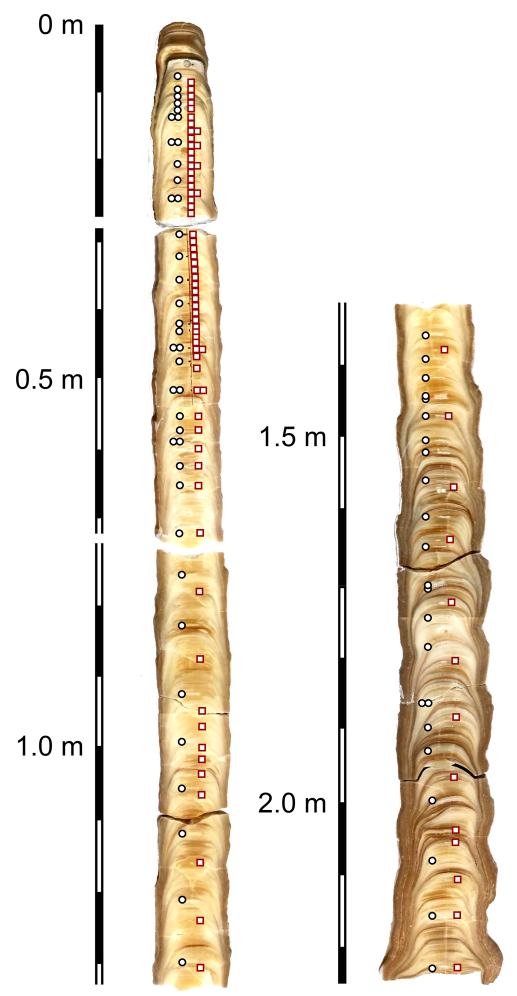

Figure 2. Composite photograph of stalagmite M1-5 from Moomi Cave. Black circles indicate where U-series dating samples were taken; red squares represent ${ }^{14} \mathrm{C}$ sample locations.

\subsection{Radiocarbon dating}

For ${ }^{14} \mathrm{C}$ measurements, approximately $10 \mathrm{mg}$ of calcite was cut with a diamond wire saw or drilled from the stalagmite along the growth layers. To avoid contamination by ambient air, the cut samples were leached in $4 \%$ hydrochloric acid before hydrolysis, whereas the powder from drilled samples was immediately processed after sampling. Hydrolysis was carried out on an evacuated glass line $\left(p<10^{-3}\right.$ mbar $)$ by adding $0.5 \mathrm{~mL}$ of $11 \%$ hydrochloric acid. The emerging water vapor during hydrolysis was removed by dry ice and acetone freezing traps. The acquired $\mathrm{CO}_{2}$ was subsequently reduced to graphite over $3-4 \mathrm{~h}$ at $575^{\circ} \mathrm{C}$ on a separate setup by adding $\mathrm{H}_{2}$ and the $\mathrm{CO}_{2}$ from the previous step to a reactor containing iron powder as a catalyst. Detailed descriptions of the sample preparation routine can be found in Fohlmeister et al. (2011) and Unkel (2006). After the reaction, the resulting graphite-iron compound was pressed into targets. A $200 \mathrm{kV}$ tandem MICADAS (mini carbon dating system) AMS at the Curt-Engelhorn-Centre Archaeometry $\mathrm{gGmbH}$ in Mannheim, Germany, was used for the measurements (Kromer et al., 2013; Synal et al., 2007). Process blanks from marble were prepared using the same method applied for regular samples to account for possible contamination during chemical preparation or sample handling before the eventual measurement in the AMS, and they yielded apparent blank activities consistently lower than $0.25 \mathrm{pmC}$ (pmC represents percent modern carbon) (apparent blank ${ }^{14} \mathrm{C}$ ages of $48-56 \mathrm{kyr}$ ). Oxalic acid II standards were graphitized from previously extracted $\mathrm{CO}_{2}$ gas and used for measurement calibration. Other international and in-house calcite standards were prepared and measured frequently to determine the full analytical measurement reproducibility. In our case, the IAEA C2 standard was measured over 2 years with a reproduced value of $40.77 \pm 0.36 \mathrm{pmC}$ compared to the assigned literature value of $41.14 \pm 0.03 \mathrm{pmC}$.

\subsection{Elemental analysis}

For measurements of $\mathrm{Mg} / \mathrm{Ca}$ ratios, approximately 1 to $2 \mathrm{mg}$ of calcite was drilled from the stalagmite at each ${ }^{14} \mathrm{C}$ sample point. At the Institute of Environmental Physics at Heidelberg University a Thermo Fisher iCAP Q inductively coupled plasma quadrupole MS (ICPQMS) was used, while data were also collected at the Institute of Earth Sciences at Heidelberg University using an ICP optical emission spectrometer (ICP-OES) 720. For the ICPQMS, the $1 \sigma$ reproducibility of the $\mathrm{Mg} / \mathrm{Ca}$ ratio of two measured standards is $<1 \%$. For the OES setup, the internal $1 \sigma$ standard deviation is $<1 \%$ for $\mathrm{Ca}^{2+}$ and $\mathrm{Mg}^{2+}$. Here SPS SW2 is used as a standard, and the long-term $1 \sigma$ reproducibility is $2.0 \%$ for $\mathrm{Ca}^{2+}$ and $3.3 \%$ for $\mathrm{Mg}^{2+}$ (Warken et al., 2018). Comparability of the results from both setups was ensured by normalizing the $\mathrm{Mg} / \mathrm{Ca}$ ratios with respect to a series of internal standard measurements that were carried out in both laboratories.

\section{Results}

\subsection{U-series chronology}

The U concentration in M1-5 ranges from $700.5 \pm 2.9$ to $2913.8 \pm 9.3 \mathrm{ppb}$, and ${ }^{232} \mathrm{Th}$ concentrations are between $15.04 \pm 0.88$ and $21042 \pm 36$ ppt.

All U-series ages in this study are reported in "years before present (yr BP)" or "kiloyears before present (kyr BP)" where BP is referring to the year 1950 . High ${ }^{238} \mathrm{U}$ and low ${ }^{232} \mathrm{Th}$ concentrations in most samples allow for very precise $\mathrm{U}$-series ages without major corrections or age reversals. Useries ages range from $27.11 \pm 0.20$ to $10.890 \pm 0.034 \mathrm{kyr} \mathrm{BP}$ with $2 \sigma$ age uncertainties from $0.2 \%$ to $1.0 \%$. The resulting chronology is in good agreement with previous results from the same sample (Shakun et al., 2007), but the higher resolution of the new U-series dates reveals the growth history in much closer detail. Except for two outliers, almost all U-series ages are in stratigraphic order and were utilized for age-depth modeling (Fig. 3). Replicate U-series age subsamples for seven different depths all agree within their $2 \sigma$ errors.

Age-depth modeling was performed using a stepwise implementation of StalAge (Scholz and Hoffmann, 2011) between the resolved growth discontinuities. The growth 


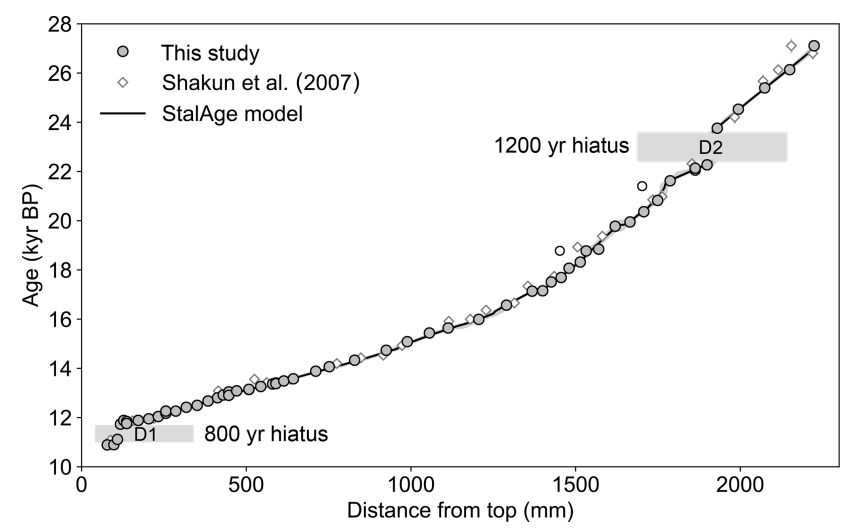

Figure 3. U-series ages vs. depth. Error bars reflect $2 \sigma$ statistical uncertainty but are mostly covered by the data points. The solid line represents the established age model obtained by sectional implementation of the StalAge algorithm (Scholz and Hoffmann, 2011). Two data points implying age inversions (empty circles) in an otherwise steady record were omitted. Diamonds represent data from a previous study (Shakun et al., 2007). Growth discontinuities D1 and D2 are highlighted by gray bars.

rate of stalagmite M1-5 is fairly constant during the last glacial termination as well as interstadials from approximately $17.2 \mathrm{kyr}$ until $11.7 \mathrm{kyr} \mathrm{BP}$ at an average growth rate of roughly $0.23 \mathrm{~mm} \mathrm{yr}^{-1}$. A distinct 800 -year hiatus was identified at $110 \mathrm{~mm}$ (from top) from 11.7 to $10.9 \mathrm{kyr} \mathrm{BP}$ (henceforth referred to as discontinuity "D1"). Above this hiatus, the stalagmite growth continued at a high rate of ap-

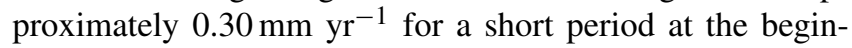
ning of the Holocene. Dating results obtained by Shakun et al. (2007), and the rapid texture and color changes of the growth layers in the uppermost part of the stalagmite above $5 \mathrm{~cm}$ from the top, indicate sporadic growth throughout the Holocene. For the older part of the stalagmite, a lower growth rate is observed: from 27.2 to $17 \mathrm{kyr} \mathrm{BP}$, the average rate is $0.086 \mathrm{~mm} \mathrm{yr}^{-1}$ with another 1200 -year-long hiatus after $23.5 \mathrm{kyr}$ BP (discontinuity "D2"). Overall, the growth is mostly continuous with two discontinuities of multicentennial duration with an overall rate of approximately $0.130 \mathrm{~mm} \mathrm{yr}^{-1}$ between 27.2 and $11 \mathrm{kyr} \mathrm{BP}$, implying a high temporal resolution of $7.5 \mathrm{yr} \mathrm{mm}^{-1}$.

The initial $\delta^{234} \mathrm{U}$ at the time of deposition $\left(\delta^{234} \mathrm{U}_{\text {init }}\right)$ can be calculated from the measured $\delta^{234} \mathrm{U}_{\text {meas }}$ by correcting it for ${ }^{234} \mathrm{U}$ decay with the determined age $t$ :

$\delta^{234} \mathrm{U}_{\text {init }}=\delta^{234} \mathrm{U}_{\text {meas }} \cdot \exp \left(\lambda_{234} \cdot t\right)$.

$\delta^{234} \mathrm{U}_{\text {init }}$ of stalagmite M1-5 is consistently below zero with minimal values of around $-130 \%$, which implies a strongly leached and subsequently ${ }^{234} \mathrm{U}$-depleted host rock. $\delta^{234} \mathrm{U}_{\text {init }}$ increases from the ${ }^{234} \mathrm{U}$-depleted LGM $\sim 21 \mathrm{kyr}$ BP towards the Bølling-Allerød warm period $(-25 \%$, 15 kyr BP) where the growth rate is significantly higher.

\subsection{Radiocarbon results}

A total of 78 stalagmite ${ }^{14} \mathrm{C}$ measurements were performed on stalagmite M1-5, including 6 duplicates for which all steps including the subsampling, preparation, and measurement were repeated. The measured ${ }^{14} \mathrm{C}$ activities $\left(a^{14} \mathrm{C}_{\text {meas }}\right)$ range between $19.52 \pm 0.20$ and $2.846 \pm 0.035 \mathrm{pmC}$. The reproducibility of ${ }^{14} \mathrm{C}$ results is assessed by long-term measurements of the international IAEA C2 standard. The resulting statistical error is used as an overall reproducibility. The total uncertainty is then calculated as the square root of the squared sum of the statistical error and overall reproducibility. Each sample was assigned a U-Th modeled age $\left(t_{\text {mod }}\right)$ from the StalAge model, revealing a generally decreasing ${ }^{14} \mathrm{C}$ activity for older parts of M1-5 but also large variations on decadal timescales. For comparison with atmospheric ${ }^{14} \mathrm{C}$ levels, the data are converted to conventional radiocarbon years $\left(t_{14} \mathrm{C}\right)$.

${ }^{t_{14} \mathrm{C}}=-8033$ years $\cdot \ln \left(a^{14} C_{\text {meas }}\right)$

The ${ }^{14} \mathrm{C}$ ages of stalagmite M1-5 are significantly older than the contemporaneous atmospheric ${ }^{14} \mathrm{C}$ calibration curve (Reimer et al., 2013). Throughout the literature, this effect in stalagmites has been referred to and quantified in many different ways. For this article, we follow the definition of "DCF" as given by Genty et al. (1999) notwithstanding that all results can be understood as an equivalent "reservoir age" in the unit "14 C years". The reporting of reservoir ages in ${ }^{14} \mathrm{C}$ studies on speleothems is described in detail by Soulet et al. (2016). In this study, the DCF varies substantially, as seen in comparison to the Hulu Cave speleothem record (Cheng et al., 2018) (Fig. 4a). Based on the StalAge model for M1-5, the initial ${ }^{14} \mathrm{C}$ activity $\left(a^{14} \mathrm{C}_{\text {init }}\right)$, at the time when the respective stalagmite layer was deposited, was reconstructed.

$a^{14} \mathrm{C}_{\text {init }}=a^{14} \mathrm{C}_{\text {meas }} \cdot \exp \left(t_{\text {mod }} / 8267\right.$ years $)$

DCF was calculated by comparing each $a^{14} \mathrm{C}_{\text {init }}$ to the atmospheric ${ }^{14} \mathrm{C}$ level $\left(a^{14} \mathrm{C}_{\mathrm{atm}}\right)$ at the respective time, as obtained from Reimer et al. (2013). $1 \sigma$ errors were calculated using a Monte Carlo approach following the procedure described in Griffiths et al. (2012).

$\mathrm{DCF}=\left[1-\frac{a^{14} \mathrm{C}_{\text {init }}}{a^{14} \mathrm{C}_{\mathrm{atm}}}\right] \cdot 100 \%$

DCF values for stalagmite M1-5 range from $27.33 \pm 0.24 \%$ at approximately $13 \mathrm{kyr} \mathrm{BP}$ to values as high as $64.6 \pm 1.1 \%$ at $20.7 \mathrm{kyr}$ BP (Fig. 4b). The M1-5 DCF record shows very high values before $18 \mathrm{kyr} \mathrm{BP}$ and a decreasing trend towards lower DCF values until $13 \mathrm{kyr}$ BP. The following period between 13 and $11 \mathrm{kyr}$ BP is characterized by higher, and highly variable, DCF values of between $40 \%$ and $50 \%$, and these values exhibit rapid fluctuations on decadal timescales as seen in a $9 \%$ drop in a time interval of only 60 years modeled age at approximately $11.9 \mathrm{kyr} \mathrm{BP}$. 


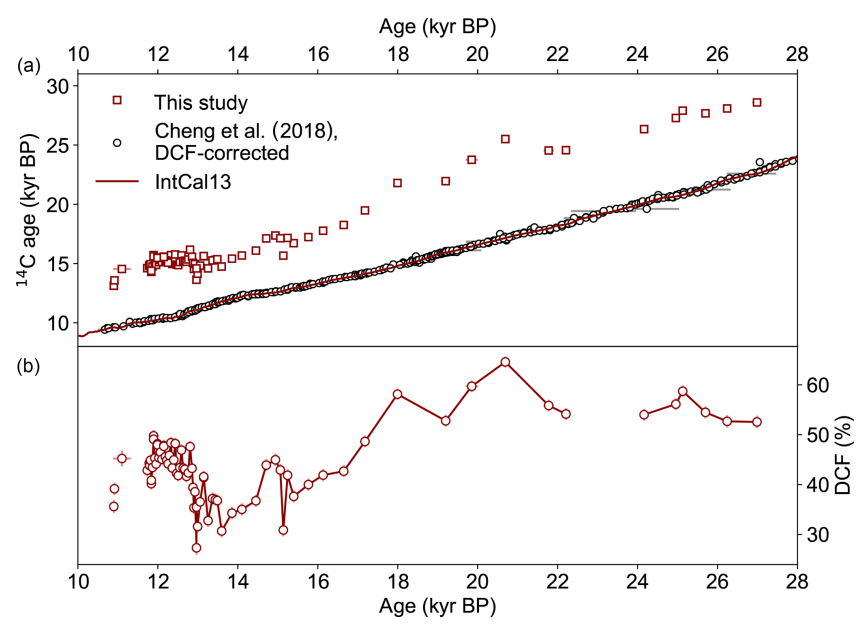

Figure 4. Upper graph (a) shows the ${ }^{14} \mathrm{C}$ ages of stalagmite M1-5 (red squares) plotted vs. age derived from the StalAge model. Error bars are mostly smaller than symbol size. Also shown is the atmospheric ${ }^{14} \mathrm{C}$ age (solid red line) from Reimer et al. (2013), with the recently published DCF-corrected stalagmite record from Cheng et al. (2018). The DCF of stalagmite M1-5 is shown in (b).

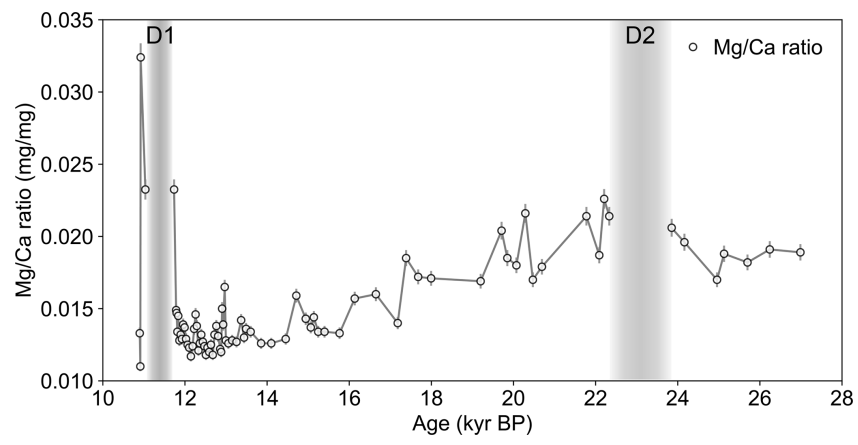

Figure 5. $\mathrm{Mg} / \mathrm{Ca}$ ratio of stalagmite carbonate vs. modeled age. Error bars reflect the data reproducibility (overall $3 \%$ of measured values). Growth discontinuities D1 and D2 are highlighted by gray bars. The data show a general decreasing trend from the LGM towards Termination I, which is interrupted by highly increased values around D1 at approximately $11.7 \mathrm{kyr}$ BP. Both hiatuses inferred from U-series dating are shaded in gray.

\section{3 $\mathrm{Mg} /$ Ca ratio}

$\mathrm{Mg} / \mathrm{Ca}$ ratios range from $0.01100 \pm 0.00033$ to $0.03217 \pm$ 0.00097 and display a continuous decrease from 22 to $12 \mathrm{kyr} \mathrm{BP}$. After this decrease, $\mathrm{Mg} / \mathrm{Ca}$ ratios rise sharply to their highest values around D1. After a few very high values, the ratio drops back to the level measured before the major excursion (Fig. 5).

\section{Discussion}

\subsection{U-series dating and age-depth model}

The revised chronology for stalagmite M1-5 is far more accurate and precise in comparison to the previously published chronology, which was based on much fewer U-series ages (Shakun et al., 2007). Average uncertainties of the corrected U-series ages have decreased from $1.19 \pm 0.30 \%$ in Shakun et al. (2007) to $0.408 \pm 0.161 \%$ in this study. The refined age record helped to identify the two growth discontinuities (see Fig. 3). ${ }^{238} \mathrm{U}$ concentrations remain fairly constant around $2 \mathrm{ppm}$ before $14 \mathrm{kyr}$ BP when a dilution effect is visible and concentrations decrease to less than $1 \mathrm{ppm}$ at $\sim 11 \mathrm{kyr}$ BP. The StalAge model reveals a general trend towards higher growth rates in the younger part of the stalagmite with the highest growth rates of $0.30 \mathrm{~mm} \mathrm{yr}^{-1}$ at around $13 \mathrm{kyr} \mathrm{BP}$, more than a factor of 2 higher than during the last glacial period. The general growth patterns can even be distinguished by mere optical examination of the stalagmite lamination. At a depth of $\sim 1.5 \mathrm{~m}(17 \mathrm{kyr} \mathrm{BP})$, a transition from marked lamination and darker colors to lighter layer coloring is visible. Synchronously, the width of the stalagmite decreases gradually from more than $15 \mathrm{~cm}$ to less than $10 \mathrm{~cm}$ in the younger half (see Fig. 2), where the growth rate is highest. According to stalagmite growth modeling studies (Dreybrodt, 1999; Kaufmann, 2003; Kaufmann and Dreybrodt, 2004), higher drip rates and higher temperatures cause a larger stalagmite diameter and higher growth rates. A rise in temperature on Socotra Island of about $2-3.5^{\circ} \mathrm{C}$ from the LGM to the Holocene was postulated by Shakun et al. (2007). A parallel increase in precipitation will be discussed in Sect. 5.3. For stalagmite M1-5, a smaller diameter is observed in a time where the drip rate most likely increased significantly, which contrasts with the aforementioned studies. Nonetheless, the times of highest growth rates correlate with both increasing precipitation and temperatures.

\subsection{DCF and implications for radiocarbon calibration}

With the implemented age model for stalagmite M1-5, the DCF can be accurately assessed for the time interval of stalagmite growth overlapping with both the dendrochronological records till $12.4 \mathrm{kyr} \mathrm{BP}$ and the wiggle-matched floating late glacial pine tree-ring chronology going back to $14 \mathrm{kyr} \mathrm{BP}$ (Hua et al., 2009; Schaub et al., 2008). Both are a substantial part of the intercalibration record IntCal13 (Reimer et al., 2013). For this reference time, the atmospheric ${ }^{14} \mathrm{C}$ concentration is well known. Figure 6 compares the record of M1-5 to the speleothem-based ${ }^{14} \mathrm{C}$ records previously implemented in IntCal13 (Reimer et al., 2013). For the time interval overlapping with the tree-ring-based atmospheric ${ }^{14} \mathrm{C}$ calibration data (including floating tree-ring chronologies), stalagmite M1-5 reveals high DCF variability over centennial and decadal timescales: between $27 \%$ at approximately 


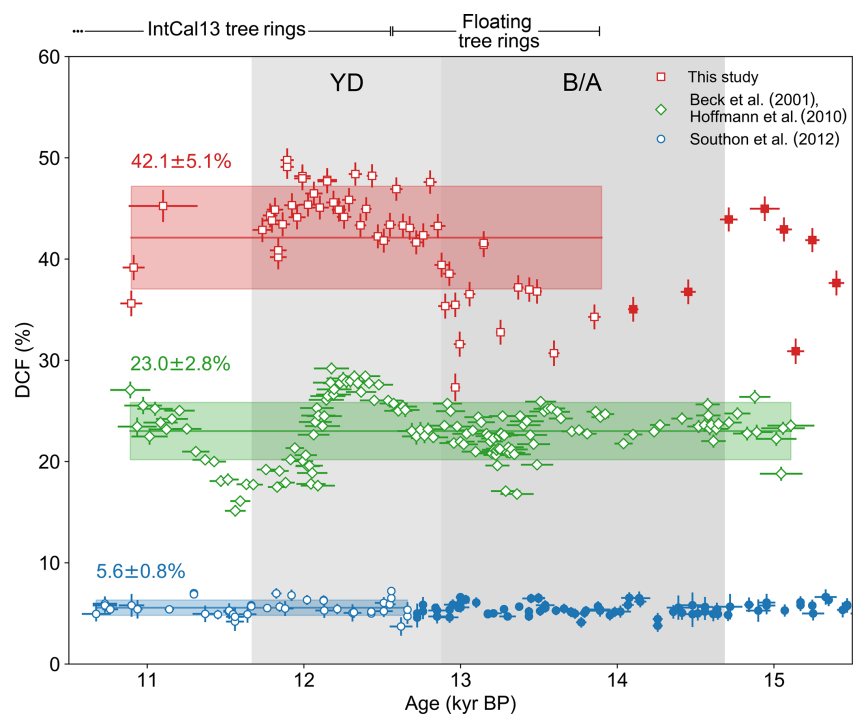

Figure 6. Very high and varying DCF for stalagmite M1-5 (this study) in comparison to records included in calibration data sets (Beck et al., 2001; Hoffmann et al., 2010; Southon et al., 2012). Whereas H82 DCF values are low and constant, the Bahamas DCF values are higher and show nonrandom structures between 11.2 and $12.7 \mathrm{kyr}$ BP. Empty symbols indicate the used reference area for the respective calibration study; the shaded colored areas represent mean values and standard deviation of DCF values in the respective reference areas. Areas of available tree-ring records (Reimer et al., 2013) are indicated on top of the graph.

$13 \mathrm{kyr} \mathrm{BP}$ and $50 \%$ at approximately $11.9 \mathrm{kyr} \mathrm{BP}$. A doubling of DCF values is observed at the onset of the YD around $12.9 \mathrm{kyr}$ BP (Fig. 6). Furthermore, rapid increases and decreases by a few percent DCF occur frequently between 12.9 and $11.9 \mathrm{kyr}$ BP. The data implicating these fluctuations have been replicated several times to exclude the possibility of outliers. This highlights the large DCF variability of stalagmite M1-5 on sub-centennial timescales, which puts this ${ }^{14} \mathrm{C}$ record in stark contrast to the IntCal13 stalagmite records.

For instance, no comparable variability is visible in the Hulu Cave speleothem, H82, in which the DCF remains rather constant at $5.6 \pm 0.8 \%$ (Southon et al., 2012). The Bahamas stalagmite records show substantial and systematic changes in DCF between 11.2 and $12.7 \mathrm{kyr}$ BP (Hoffmann et al., 2010), which coincides with the YD cold reversal and was therefore attributed by the authors to vast changes in local vegetation and climatic conditions. Regardless of these effects and the resulting large uncertainty in the corrected atmospheric ${ }^{14} \mathrm{C}$ concentrations, the Bahamas record was included in the IntCal13 data, as the benchmark Hulu Cave record was not available. The ${ }^{14} \mathrm{C}$ record of stalagmite M15 does not predominantly reflect atmospheric ${ }^{14} \mathrm{C}$ variations due to the large offset to the atmosphere and the high variability across the tree-ring-based period. Hence, M1-5 cannot be used as a contribution to atmospheric ${ }^{14} \mathrm{C}$ calibra- tion. This finding is in contrast to the Hulu Cave speleothems which come from an a priori comparable temperate setting, which is under the influence of pronounced monsoonal patterns (Southon et al., 2012).

Potential atmospheric ${ }^{14} \mathrm{C}$ variations are overprinted in stalagmite M1-5 by sub-centennial changes in DCF, which must be driven by site-specific factors such as changes of soil carbon age, open- vs. closed-system conditions (Fohlmeister et al., 2011; Griffiths et al., 2012), or short-term developments affecting soil carbon dynamics above Moomi Cave. Other potentially relevant mechanisms include the influence of non-carbonic acids such as sulfuric acid (Bajo et al., 2017). Since most of the aforementioned factors are influenced by climate, stalagmite M1-5 provides an excellent opportunity to study climatic controls on the DCF values in stalagmites.

\subsection{Climatic controls of DCF at Moomi Cave}

Low DCF values in stalagmites are primarily caused by open-system recharge conditions, with enhanced uptake of soil $\mathrm{CO}_{2}$ and limited water-bedrock interaction. Both conditions prevail at Hulu Cave, where the seepage water percolates through predominantly sandstone rather than carbonate limestone (Cheng et al., 2018). In our study very high average DCF values of $56.2 \pm 3.4 \%$ are revealed during the last glacial period between 18 and $27 \mathrm{kyr}$ BP with a maximum of $65 \%$ at approximately $20.6 \mathrm{kyr} \mathrm{BP}$ (Fig. 7a). Such high DCF values are only conceivable under closed-system limestone-dissolution conditions (Hendy, 1971). However, in the conventional approach, considering only the two carbon end-members from near-atmospheric soil gas $\mathrm{CO}_{2}$ and the ${ }^{14} \mathrm{C}$-free carbonate from dissolved limestone, DCF can reach maximum values of $50 \%$ (Fohlmeister et al., 2011; Griffiths et al., 2012; Hendy, 1971). DCF values higher than $50 \%$ have been recently reported in a speleothem from Corchia Cave (Italy) as a suggested consequence of additional dead carbon input by enhanced limestone carbonate contribution to DIC through the presence of other organic or non-organic (sulfuric) acids in the soil zone (Bajo et al., 2017). This process also influences stable carbon isotopes in the stalagmite calcite, i.e., $\delta^{13} \mathrm{C}$, which shift values towards those observed in the limestone host rock. However, overall $\delta^{13} \mathrm{C}$ in M15 (Fig. 7c) primarily ranges between -4 and $-8 \%$ (average $-6.2 \pm 1.4 \%$ ) with corresponding DCF values varying from $27 \%$ to $65 \%$. Furthermore, no significant correlation between $\delta^{13} \mathrm{C}$ and DCF can be observed $\left(r^{2}=0.206\right.$, $p<0.01)$ in M1-5. It is therefore unlikely that increased limestone dissolution by sulfuric acids is the key factor for DCF variations in stalagmite M1-5. Alternatively, aged SOM could cause the observed enhanced DCF values (Genty et al., 2001). Fresh labile soil organic matter, as well as older carbon stocks in deeper soil layers on the Moomi Plateau, may have contributed to soil gas $\mathrm{CO}_{2}$, creating ${ }^{14} \mathrm{C}$-depleted $\mathrm{CO}_{2}$ (Fohlmeister et al., 2011; Trumbore, 2009). The pres- 


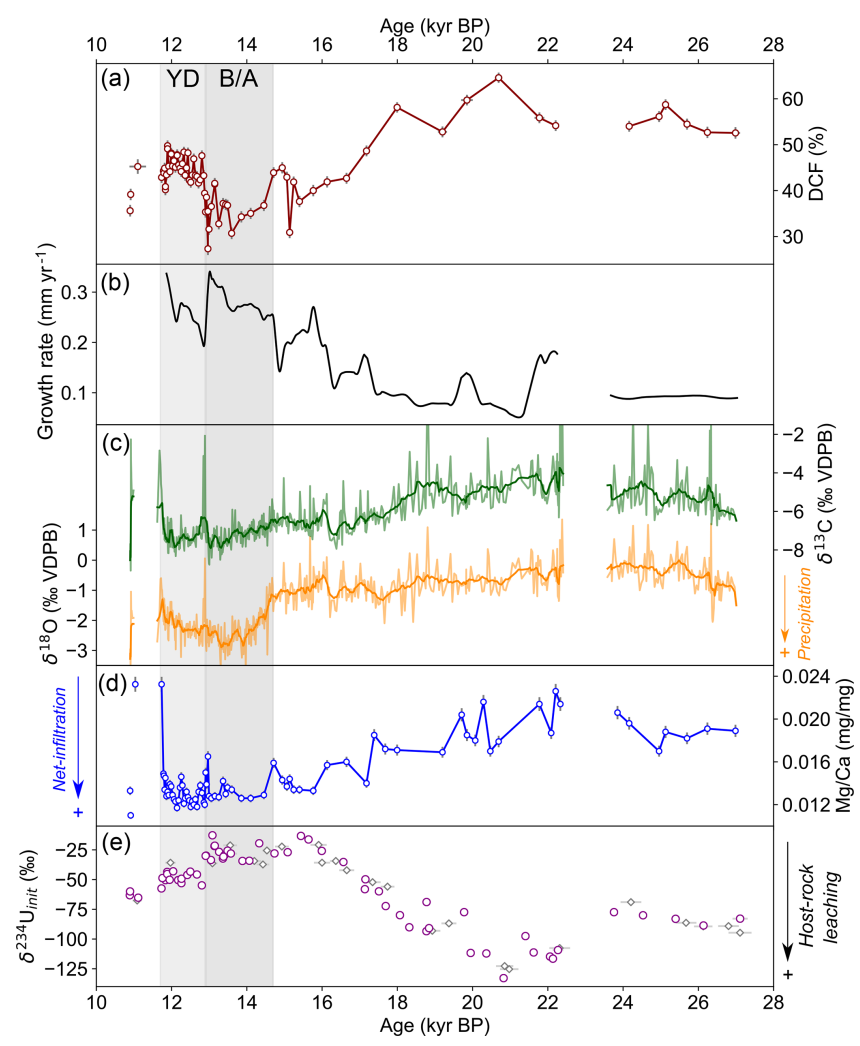

Figure 7. Combined results from stalagmite M1-5. DCF (a), growth rate from StalAge modeling (b), adapted stable isotope data from Shakun et al. (2007) (c), $\mathrm{Mg} / \mathrm{Ca}$ mass ratio (d), and $\delta^{234} \mathrm{U}$ from this study (violet circles) and Shakun et al. (2007) (gray diamonds) (e). The gray bars indicate Bølling-Allerød interstadial (B/A) and Younger Dryas (YD) cold reversal. Oxygen data were interpreted as an increase in monsoonal rainfall over Termination I. This is corroborated by $\mathrm{Mg} / \mathrm{Ca}$ precipitation proxy data, showing its lowest values in the YD, where growth rate is highest, with a decreasing trend over the end of the last glacial period. DCF shows an obvious decreasing trend after the LGM until it increases at the onset of YD. $\delta^{18} \mathrm{O}$ reaches its lowest values during the $\mathrm{B} / \mathrm{A}$ warm period, indicating an intensified monsoonal precipitation (Shakun et al., 2007).

ence of (aging) organic matter in the soil above the cave is corroborated by several studies describing the modern vegetation on Socotra Island and its limestone plateaus (Mies and Beyhl, 1998; Popov, 2008). They observed a mixture of annual grass vegetation and permanent scrubland on the limestone plateaus as well as populations of the endemic Dracaena cinnabari species. Moreover, in sheltered valleys, where the soil is well developed, dense thickets occur. In the rocky surface on the limestone plateaus, pockets of dark rich soil can form (Popov, 2008), giving rise to stabilizing carbon pools, where soil matter can aggregate and decay over long periods, thus contributing to the soil $\mathrm{CO}_{2}$ reservoir.

Together with nearly closed-system karst dissolution conditions, the ${ }^{14} \mathrm{C}$-depleted $\mathrm{CO}_{2}$ can cause $\mathrm{DCF}$ values higher than $50 \%$. For instance, if an extreme case baseline DCF of $50 \%$ under closed-system conditions is assumed for the record before $18 \mathrm{kyr} \mathrm{BP}$, an age of the active carbon pool of $2500-3000$ years can generate DCF values between $63 \%$ and $65 \%$. If the carbon pool is composed of one young (root respiration) and one old carbon reservoir (microbial decomposition of aged SOM) in equal proportions, the aged carbon contributing to soil $\mathrm{CO}_{2}$ must be older than 5000 years and contribute a share of $50 \%$ to the soil gas budget to cause such extreme DCF values. None of these scenarios have been reported before in a study on speleothem ${ }^{14} \mathrm{C}$, which makes M1-5 a unique record in terms of aged SOM contribution to stalagmite DCF.

All available geochemical proxies (shown in Fig. 7) including DCF (Fig. 7a) reflect a clear climate signal: the LGM is manifested in this stalagmite by low net-infiltration levels and rather low precipitation on the archipelago (Shakun et al., 2007). In a recent study by DiNezio et al. (2018) it was argued that the exposure of the Sahul shelf during the Last Glacial Maximum created a positive ocean-atmosphere feedback loop causing a drier and wetter dipole across the Indian Ocean and subsequent hydroclimate changes, i.e., reduced moisture levels in the Arabian Sea. The M1-5 multiproxy record suggests that towards the end of the glacial period the regional climatic conditions on Socotra Island likely shifted to a higher net infiltration which is reflected in a systematic long-term decrease of the $\mathrm{Mg} / \mathrm{Ca}$ ratio from approximately 20 to $15 \mathrm{kyr} \mathrm{BP}$. We interpret the $\mathrm{Mg} / \mathrm{Ca}$ decrease here as a proxy for incongruent host rock dissolution and prior calcite precipitation effect, reflecting shifts from drier to wetter conditions above the cave (Fairchild et al., 2000), while peaks in $\mathrm{Mg} / \mathrm{Ca}$ coincide with the two growth discontinuities and thus dry periods. This interpretation is supported by numerous studies that showed a negative correlation between $\mathrm{Mg} / \mathrm{Ca}$ ratio in stalagmite calcite and precipitation amount (Fairchild and Treble, 2009; Flohr et al., 2017; Noronha et al., 2014; Warken et al., 2018).

$\delta^{234} \mathrm{U}_{\text {init }}$ can also be used to derive changes in infiltration and thus drip rate (Dreybrodt, 1999). In our study, the increasing but still negative values in $\delta^{234} \mathrm{U}_{\text {init }}$ (Fig. 7e) after $22 \mathrm{kyr}$ BP point to a shift towards less leached host rocks or a stronger contribution of excess ${ }^{234} \mathrm{U}$ from the leached rocks. This change coincides with a doubling of the growth rate from slightly below 0.10 to more than $0.20 \mathrm{~mm} \mathrm{yr}^{-1}$, suggesting that $\delta^{234} \mathrm{U}_{\text {init }}$ is influenced by infiltration changes. It may also be affected by the geochemical composition of the seepage water (Zhou et al., 2005). However, in comparison to the other proxies for this record, it appears most likely that the drip rate in Moomi Cave has increased due to higher net infiltration. Therefore, our record contrasts with the findings of Dreybrodt (1999) and Kaufmann and Dreybrodt (2004) where higher drip rate is correlated to increased stalagmite width. Stalagmite M1-5, on the other hand, decreases in width (see Fig. 2) towards higher infiltration in a time where temperatures have increased by $2-3.5^{\circ} \mathrm{C}$ and 
precipitation rises (Shakun et al., 2007). This climatic shift is initiated during peak glacial conditions at $20 \mathrm{kyr} \mathrm{BP}$, and it is also reflected in higher seepage water excess ${ }^{234} \mathrm{U}$, as marked through the vanishing depletion of ${ }^{234} \mathrm{U}(-25 \%$ after $16 \mathrm{kyr} \mathrm{BP})$.

The inferred increase in precipitation over Socotra Island after the LGM coincides with the steady warming of the Southern Hemisphere until $15 \mathrm{kyr}$ BP. Synchronously, $\delta^{13} \mathrm{C}$ decreases by $2 \%$ and reveals sub-centennial variability of the speleothem calcite composition. During the time in which the Northern Hemisphere climate goes through swings between the warm and humid B/A and cold and dry YD (Ivanochko et al., 2005; Schulz et al., 1998), $\delta^{13} \mathrm{C}$ and $\mathrm{Mg} / \mathrm{Ca}$ in M1-5 remain at their respective lowest values. In contrast to $\delta^{13} \mathrm{C}$ values, the $\delta^{18} \mathrm{O}$ values show a moderate decrease of $1.5 \%$ across Termination I (20-11 kyr BP), which occurs rather suddenly at $\sim 14.8-15 \mathrm{kyr}$ BP. Stalagmite M1$5 \delta^{18} \mathrm{O}$ values are mainly interpreted in terms of the so-called "amount effect", describing the negative correlation between rainfall amount and $\delta^{18} \mathrm{O}$ (Dykoski et al., 2005; Griffiths et al., 2010). Shakun et al. (2007) have used this relation to infer a rise in rainfall towards the end of the last glacial, especially after $15 \mathrm{kyr}$ BP. Both stable isotopes thus share a common deglacial climate trend with punctuated strong correlation during growth perturbations (dry events), but they differ significantly through the period from 19 to $14 \mathrm{kyr}$ BP, indicating a dominant influence of vegetation above the cave which affected $\delta^{13} \mathrm{C}$ but not $\delta^{18} \mathrm{O}$. The decoupling of $\delta^{18} \mathrm{O}$ and $\delta{ }^{13} \mathrm{C}$ might also be a representation of regional moisture dynamics as described by Cheng et al. (2016) for a monsoon stalagmite record from central Asia. In that study, the correlation of $\delta^{13} \mathrm{C}$ and $\mathrm{Mg} / \mathrm{Ca}$ in combination with out-of-phase $\delta^{18} \mathrm{O}$ suggested wetter hydrological conditions, but not necessarily an increase in precipitation amount. Similar observations were made by Myers et al. (2015) for northeastern Indian stalagmites where $\delta^{18} \mathrm{O}$ was attributed to reflect changes in monsoonal moisture transport routes or sources rather than rainfall amount. On Socotra Island, seasonal shifts towards more distributed rainfall at the end of the last glacial may have changed the soil net infiltration without significant amount changes visible in $\delta^{18} \mathrm{O}$, and thus they cause wetter conditions above Moomi Cave.

Although all available proxies point to an increase in precipitation or net infiltration after the LGM, M1-5 ${ }^{14} \mathrm{C}$ data do not reflect the processes predicted if the established dependence of calcite dissolution systematics on soil infiltration holds. In contrast to studies from zones more humid when compared to Socotra Island (Genty et al., 2001; Griffiths et al., 2012; Lechleitner et al., 2016; Noronha et al., 2014), the predicted positive feedback of rainfall amount on DCF does not appear to apply here. Instead, increasing rainfall and the respective increase in infiltration seem to go along with a shift to a less closed carbonate dissolution system and an increased forcing towards higher ${ }^{14} \mathrm{C}$ levels in the soil gas $\mathrm{CO}_{2}$ by enhanced root respiration compared to a decreasing contribution by $\mathrm{CO}_{2}$, which originates from the decomposition of aged SOM. This decoupling of precipitation and DCF is evidence for a climate-induced forcing on stalagmite ${ }^{14} \mathrm{C}$, which is at least to some extent independent of the direct influence of soil humidity on calcite dissolution. On Socotra Island the precipitation is sparse and occurs only seasonally when the ITCZ crosses the archipelago. A proposed scenario for the interpretation of M1-5 is that the vegetation in (semi)arid regions like Socotra Island (in contrast to temperate, more humid settings) is much more sensitive to small changes in net infiltration. Previous studies showed that an increased monsoonal activity during Termination I (Gupta et al., 2003; Overpeck et al., 1996; Shakun et al., 2007) can have dramatic effects on the prevalence and spread of plants in arid and semiarid areas (Lotsch et al., 2003). Hence, for this study, an increase in soil $\mathrm{CO}_{2}$ input by active vegetation caused by increasing net infiltration or precipitation at the end of the last glacial period is most likely the cause for the observed soil carbon dynamics, ultimately causing strongly decreased DCF.

Since the ITCZ passes Socotra Island twice a year, causing increased precipitation, the question that arises is whether the observed trends are linked to a shift in the seasonal patterns of either summer or winter monsoon season or the intermediate ITCZ migration. Overall, we can only speculate on the role of the monsoon in shifting the local climate from a glacial, possibly Southern Hemisphere-driven, state with a stable state aged soil carbon pool (summer-monsoondriven) to a Northern Hemisphere (or mixed) state beyond $15.5 \mathrm{kyr}$ BP with an increasingly labile non-steady-state soil carbon age profile.

Consequently, we have traced a clear multimillennial increase in precipitation on the archipelago from the LGM to the $15 \mathrm{kyr}$ Northern Hemisphere sudden warming, which is accompanied by major changes in soil activity and thus vegetation.

\subsection{Glacial termination climate dynamics on Socotra Island}

Beyond the strong $\mathrm{B} / \mathrm{A}$ warming, the tracers resolve subcentennial variability of DCF, $\delta^{234} \mathrm{U}_{\text {init }}$, and $\mathrm{Mg} / \mathrm{Ca}$. This is possibly indicative of a strong local climate-monsoon coupling that is only resolved in the area with the highest temporal data density in the record. Nonetheless, one striking feature stands out: at approximately $13 \mathrm{kyr}$ BP, DCF abruptly jumps to values higher than $40 \%$, indicating sudden changes in soil carbon cycling. It was argued that sudden events caused by climatic variations or wildfires can have a major influence on soil carbon dynamics (Treble et al., 2016; Trumbore, 2009). For instance, an event like a wildfire or landslide could have drastically changed the soil configuration by depleting active vegetation and thus halting $\mathrm{CO}_{2}$ input at near-atmospheric ${ }^{14} \mathrm{C} /{ }^{12} \mathrm{C}$ ratios (Coleborn et al., 2016; Markowska et al., 2019), and it could, therefore, ac- 


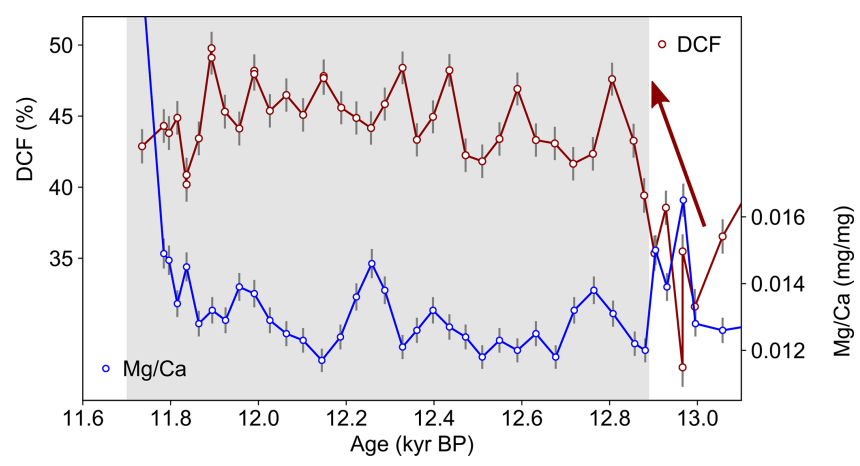

Figure 8. $\mathrm{DCF}$ and $\mathrm{Mg} / \mathrm{Ca}$ of stalagmite M1-5 for the YD (gray area). DCF increases sharply at the onset of the YD (red arrow). The high data resolution reveals pronounced changes in DCF on extremely short time periods, highlighting the vast soil dynamics during the YD where growth rate was very high $\left(>0.20 \mathrm{~mm} \mathrm{yr}^{-1}\right)$. The hydrological proxy $\mathrm{Mg} / \mathrm{Ca}$ ratio remains relatively low, indicating a high infiltration rate. The correlation between $\mathrm{DCF}$ and $\mathrm{Mg} / \mathrm{Ca}$ ratio is insignificant in this time $\left(r^{2}=0.23, p<0.01\right)$.

count for the sudden increase in DCF. Except for short-term excursions, all other proxies remain at virtually the same levels on average over the event with $\mathrm{Mg} / \mathrm{Ca}$ ratios indicating persistent high precipitation during the YD. Hence, this feature of the M1-5 record is only visible in the ${ }^{14} \mathrm{C}$ data.

The high-resolution data from speleothem M1-5 (exemplified by $\mathrm{DCF}$ and $\mathrm{Mg} / \mathrm{Ca}$ records in Fig. 8) reveal marked variability in DCF on sub-centennial timescales, exemplified by a sudden decrease of almost $10 \%$ within less than 100 years. Several of these peaks can be seen throughout the whole period of high temporal resolution, although they are not represented in $\mathrm{Mg} / \mathrm{Ca}$ variations, and correlation in this period is insignificant $\left(r^{2}=0.231, p<0.01\right)$. The high DCF volatility suggests a pronounced influence of local effects on the soil carbon dynamics on the Moomi Plateau. Other proxies, while still showing some sub-centennial variability, do not suggest a persistent change for the YD. $\delta^{13} \mathrm{C}$ values remain at comparable levels at the end of the glacial period, which indicates a high influence of organic or biogenic $\mathrm{CO}_{2}$ on stalagmite formation and contradicts enhanced limestone carbonate dissolution. $\delta^{18} \mathrm{O}$ values remain roughly within the state which suggests intensified precipitation during B/A, which was attributed to a stronger monsoon (Shakun et al., 2007). Hence, a persistent change in climatic conditions on Socotra Island appears not likely for the YD. Although from our data we cannot conclusively derive the direct cause for the observed fluctuations in DCF, which are not represented in hydrological proxies, we propose that labile conditions of the soil carbon pool above the cave or short-term changes in carbonate dissolution systematics might have played a vital role.

\section{Conclusions}

Stalagmite M1-5 from Moomi Cave, Socotra Island, might at face value seem similar to other speleothems that have been used for atmospheric ${ }^{14} \mathrm{C}$ calibration. Precise U-series dating revealed an overall growth rate of more than $0.13 \mathrm{~mm} \mathrm{yr}^{-1}$. The geographical setting in a subtropical climate in the western Arabian Sea under the influence of the East AfricanIndian monsoon is comparable to those of the Bahamas and Hulu Cave speleothems (Beck et al., 2001; Hoffmann et al., 2010; Southon et al., 2012) that have contributed to ${ }^{14} \mathrm{C}$ calibration. However, the DCF values of M1-5 are very high, being among the highest that have been reported, and additionally show distinct trends over the entire growth period of the stalagmite, thus proving the climatic impact on speleothem ${ }^{14} \mathrm{C}$. Large short-term DCF changes on sub-centennial timescales emphasize the importance of local carbon-cycling variability on stalagmite ${ }^{14} \mathrm{C}$. Whereas the Hulu Cave record (Cheng et al., 2018; Southon et al., 2012), with its low DCF that remains constant even during pronounced climate changes, has been referred to as the "Holy Grail of ${ }^{14} \mathrm{C}$ dating", records like M1-5 are crucial for the understanding of soil carbon cycling and karst hydrogeochemistry.

We conclude that M1-5 grew under near-closed conditions with a high influence of aged SOM prevailing throughout the LGM. This causes the DCF to exceed its theoretical maximum of $50 \%$ before increasing precipitation and wetter conditions triggered a gradual increase in ${ }^{14} \mathrm{C}$-enriched $\mathrm{CO}_{2}$ input, most likely caused by denser vegetation coverage on the plateau above the cave.

With most proxies pointing to a higher net-infiltration rate towards Termination I, M1-5 shows a trend opposed to previous observations, suggesting a positive correlation between soil humidity and DCF due to the influence of hydrology on carbonate dissolution. Rather, the data reveal a probable intensified vegetation occurrence on the Moomi Plateau, causing a higher influx of $\mathrm{CO}_{2}$ at high ${ }^{14} \mathrm{C}$ levels into the soil gas regime that shifts DCF to lower levels. These findings motivate the implementation of ${ }^{14} \mathrm{C}$ in stalagmites as a tracer for vegetation and emphasize the distinction between temperate and humid settings and semiarid or arid regions when assessing the influence of precipitation changes on DCF in stalagmites. Soil carbon dynamics and the influence of vegetation and SOM seem to exert significant forcings on DCF, exemplified in our record by both the long-term trend towards Termination I and the significant variability on sub-centennial timescales during the YD.

Our work is an important contribution to future efforts to understand soil dynamics and their connection to stalagmite DCF, in particular as this bears on the search for suitable ${ }^{14} \mathrm{C}$ calibration records. 
Data availability. The data presented in this paper were uploaded to the PANGAEA data library and are available at https://doi.org/10.1594/PANGAEA.906003 (Therre et al., 2019).

Author contributions. The scientific project was designed and conducted by ST, JF, and NF. ST performed the sampling for all measurements and the data evaluation and wrote the paper with contributions by the other co-authors. JA performed the U-series measurements and quality assessment. AM and SJB played a major role in the investigations and expedition that led to the collection of the stalagmite. RF conducted the ${ }^{14} \mathrm{C}$ measurements. ASR performed the elemental measurements. All co-authors contributed to the discussion of the results and interpretations.

Competing interests. The authors declare that they have no conflict of interest.

Acknowledgements. We thank René Eichstädter at the Institute of Environmental Physics for conducting the MC-ICP-MS measurements with the help of Sandra Rybakiewicz, Hanna Rosenthal, and Carla Roesch, as well as Marleen Lausecker for the ICPQMS measurements. We are grateful to Silvia Rheinberger and Christian Scholz for the elemental measurements at the Institute of Earth Sciences at Heidelberg University. We thank Evan C. Border for his help concerning the language of the article.

The authors are very grateful to the editor Luke Skinner and to two anonymous referees for their constructive feedback and suggestions. Their comments considerably improved the quality of our article.

Financial support. This research has been supported by the DFG (grant nos. FR1341/4-1, FO809/2-1 and INST35-1143-1 FUGG). This project is TiPES contribution no. 14: this project has received funding from the European Union's Horizon 2020 research and innovation programme under grant agreement no. 820970 .

Review statement. This paper was edited by Luke Skinner and reviewed by two anonymous referees.

\section{References}

Adolphi, F., Muscheler, R., Friedrich, M., Güttler, D., Wacker, L., Talamo, S., and Kromer, B.: Radiocarbon calibration uncertainties during the last deglaciation: Insights from new floating tree-ring chronologies, Quaternary Sci. Rev., 170, 98-108, https://doi.org/10.1016/j.quascirev.2017.06.026, 2017.

Arnold, J. R. and Libby, W. F.: Age determinations by radiocarbon content: Checks with samples of known age, Science, 110, 678680, https://doi.org/10.1126/science.110.2869.678, 1949.

Arps, J.: Towards $\varepsilon$-Precision of U-series Age Determinations of Secondary Carbonates, Heidelberg University, 2017.

Bajo, P., Borsato, A., Drysdale, R., Hua, Q., Frisia, S., Zanchetta, G., Hellstrom, J., and Woodhead, J.: Stalagmite carbon iso- topes and dead carbon proportion (DCP) in a near-closedsystem situation: An interplay between sulphuric and carbonic acid dissolution, Geochim. Cosmochim. Ac., 210, 208-227, https://doi.org/10.1016/j.gca.2017.04.038, 2017.

Beck, J. W., Richards, D. A., Edwards, R. L., Silverman, B. W., Smart, P. L., Donahue, D. J., Hererra-Osterheld, S., Burr, G. S., Calsoyas, L., Jull, A. J. T., and Biddulph, D.: Extremely large variations of atmospheric ${ }^{14} \mathrm{C}$ concentration during the last glacial period, Science, 292, 2453-2458, https://doi.org/10.1126/science.1056649, 2001.

Burns, S. J.: Indian Ocean Climate and an Absolute Chronology over Dansgaard/Oeschger Events 9 to 13, Science, 301, 13651367, https://doi.org/10.1126/science.1086227, 2003.

Cheng, H., Edwards, R. L., Hoff, J., Gallup, C. D., Richards, D. A., and Asmerom, Y.: The half-lives of uranium-234 and thorium230, Chem. Geol., 169, 17-33, https://doi.org/10.1016/S00092541(99)00157-6, 2000.

Cheng, H., Spötl, C., Breitenbach, S. F. M., Sinha, A., Wassenburg, J. A., Jochum, K. P., Scholz, D., Li, X., Yi, L., Peng, Y., Lv, Y., Zhang, P., Votintseva, A., Loginov, V., Ning, Y., Kathayat, G., and Edwards, R. L.: Climate variations of Central Asia on orbital to millennial timescales, Sci. Rep., 6, 36975, https://doi.org/10.1038/srep36975, 2016.

Cheng, H., Lawrence Edwards, R., Southon, J., Matsumoto, K., Feinberg, J. M., Sinha, A., Zhou, W., Li, H., Li, X., Xu, Y., Chen, S., Tan, M., Wang, Q., Wang, Y., and Ning, Y.: Atmospheric ${ }^{14} \mathrm{C} /{ }^{12} \mathrm{C}$ changes during the last glacial period from Hulu Cave, Science, 362, 1293-1297, https://doi.org/10.1126/science.aau0747, 2018.

Coleborn, K., Spate, A., Tozer, M., Andersen, M. S., Fairchild, I. J., MacKenzie, B., Treble, P. C., Meehan, S., Baker, A., and Baker, A.: Effects of wildfire on long-term soil $\mathrm{CO}_{2}$ concentration: implications for karst processes, Environ. Earth Sci., 75, 330, https://doi.org/10.1007/s12665-015-4874-9, 2016.

DiNezio, P. N., Tierney, J. E., Otto-Bliesner, B. L., Timmermann, A., Bhattacharya, T., Rosenbloom, N., and Brady, E.: Glacial changes in tropical climate amplified by the Indian Ocean, Sci. Adv., 4, 12, https://doi.org/10.1126/sciadv.aat9658, 2018.

Douville, E., Sallé, E., Frank, N., Eisele, M., Pons-Branchu, E., and Ayrault, S.: Rapid and accurate U-Th dating of ancient carbonates using inductively coupled plasmaquadrupole mass spectrometry, Chem. Geol., 272, 1-11, https://doi.org/10.1016/j.chemgeo.2010.01.007, 2010.

Dreybrodt, W.: Chemical kinetics, speleothem growth and climate, Boreas, 28, 347-356, https://doi.org/10.1111/j.15023885.1999.tb00224.x, 1999.

Dykoski, C. A., Edwards, R. L., Cheng, H., Yuan, D., Cai, Y., Zhang, M., Lin, Y., Qing, J., An, Z., and Revenaugh, J.: A highresolution, absolute-dated Holocene and deglacial Asian monsoon record from Dongge Cave, China, Earth Planet. Sc. Lett., 233, 71-86, https://doi.org/10.1016/j.epsl.2005.01.036, 2005.

Fairchild, I. J. and Treble, P. C.: Trace elements in speleothems as recorders of environmental change, Quaternary Sci. Rev., 28, 449-468, https://doi.org/10.1016/j.quascirev.2008.11.007, 2009.

Fairchild, I. J., Borsato, A., Tooth, A. F., Frisia, S., Hawkesworth, C. J., Huang, Y., McDermott, F., and Spiro, B.: Controls on trace element ( $\mathrm{Sr}-\mathrm{Mg}$ ) compositions of carbonate cave waters: Implications for speleothem climatic records, Chem. Geol., 166, 255269, https://doi.org/10.1016/S0009-2541(99)00216-8, 2000. 
Fleitmann, D., Burns, S. J., Mudelsee, M., Neff, U., Kramers, J., Mangini, A., and Matter, A.: Holocene forcing of the Indian monsoon recorded in a stalagmite from southern Oman, Science, 300, 1737-9, https://doi.org/10.1126/science.1083130, 2003.

Fleitmann, D., Burns, S. J., Mangini, A., Mudelsee, M., Kramers, J., Villa, I., Neff, U., Al-Subbary, A. A., Buettner, A., Hippler, D., and Matter, A.: Holocene ITCZ and Indian monsoon dynamics recorded in stalagmites from Oman and Yemen (Socotra), Quaternary Sci. Rev., 26, 170-188, https://doi.org/10.1016/j.quascirev.2006.04.012, 2007.

Flohr, P., Fleitmann, D., Zorita, E., Sadekov, A., Cheng, H., Bosomworth, M., Edwards, L., Matthews, W., and Matthews, R.: Late Holocene droughts in the Fertile Crescent recorded in a speleothem from northern Iraq, Geophys. Res. Lett., 44, 15281536, https://doi.org/10.1002/2016GL071786, 2017.

Fohlmeister, J., Kromer, B., and Mangini, A.: The influence of soil organic matter age spectrum on the reconstruction of atmospheric ${ }^{14} \mathrm{C}$ levels via stalagmites, Radiocarbon, 53, 99-115, https://doi.org/10.1017/S003382220003438X, 2011.

Genty, D., Massault, M., Gilmour, M., Baker, A., Verheyden, S., and Kepens, E.: Calculation of past dead carbon proportion and variability by the comparison of AMS(14)C and TIMS U/Th ages on two holocene stalagmites, Radiocarbon, 41, 251-270, https://doi.org/10.1017/S003382220005712X, 1999.

Genty, D., Baker, A., Massault, M., Proctor, C., Gilmour, M., Pons-Branchu, E., and Hamelin, B.: Dead carbon in stalagmites: Carbonate bedrock paleodissolution vs. ageing of soil organic matter. Implications for ${ }^{13} \mathrm{C}$ variations in speleotherms, Geochim. Cosmochim. Ac., 65, 3443-3457, https://doi.org/10.1016/S0016-7037(01)00697-4, 2001.

Griffiths, M. L., Drysdale, R. N., Gagan, M. K., Frisia, S., Zhao, J. xin, Ayliffe, L. K., Hantoro, W. S., Hellstrom, J. C., Fischer, M. J., Feng, Y. X., and Suwargadi, B. W.: Evidence for Holocene changes in Australian-Indonesian monsoon rainfall from stalagmite trace element and stable isotope ratios, Earth Planet. Sc. Lett., 292, 27-38, https://doi.org/10.1016/j.epsl.2010.01.002, 2010.

Griffiths, M. L., Fohlmeister, J., Drysdale, R. N., Hua, Q., Johnson, K. R., Hellstrom, J. C., Gagan, M. K., and Zhao, J. X.: Hydrological control of the dead carbon fraction in a Holocene tropical speleothem, Quat. Geochronol., 14, 81-93, https://doi.org/10.1016/j.quageo.2012.04.001, 2012.

Gupta, A. K., Anderson, D. M., and Overpeck, J. T.: Abrupt changes in the Asian southwest monsoon during the holocene and their links to the North Alantic Ocean, Nature, 421, 354357, https://doi.org/10.1038/nature01340, 2003.

Hendy, C.: The isotopic geochemistry of speleothems - I. The calculation of the effects of different modes of formaion on the isotopic composition of speleothems and their applicability as paleoclimatic indicators, Geochim. Cosmochim. Ac., 35, 801-824, https://doi.org/10.1016/0016-7037(71)90127-X, 1971.

Hoffmann, D. L., Beck, J. W., Richards, D. A., Smart, P. L., Singarayer, J. S., Ketchmark, T., and Hawkesworth, C. J.: Towards radiocarbon calibration beyond $28 \mathrm{ka}$ using speleothems from the Bahamas, Earth Planet. Sc. Lett., 289, 110, https://doi.org/10.1016/j.eps1.2009.10.004, 2010.

Hua, Q., Barbetti, M., Fink, D., Kaiser, K. F., Friedrich, M., Kromer, B., Levchenko, V. A., Zoppi, U., Smith, A. M., and Bertuch, F.: Atmospheric ${ }^{14} \mathrm{C}$ variations derived from tree rings during the early Younger Dryas, Quaternary Sci. Rev., 28, 2982-2990, https://doi.org/10.1016/j.quascirev.2009.08.013, 2009.

Ivanochko, T. S., Ganeshram, R. S., Brummer, G. J. A., Ganssen, G., Jung, S. J. A., Moreton, S. G., and Kroon, D.: Variations in tropical convection as an amplifier of global climate change at the millennial scale, Earth Planet. Sc. Lett., 235, 302-314, https://doi.org/10.1016/j.epsl.2005.04.002, 2005.

Kaufmann, G.: Stalagmite growth and palaeo-climate: The numerical perspective, Earth Planet. Sc. Lett., 214, 251-266, https://doi.org/10.1016/S0012-821X(03)00369-8, 2003.

Kaufmann, G. and Dreybrodt, W.: Stalagmite growth and palaeoclimate: An inverse approach, Earth Planet. Sc. Lett., 224, 529545, https://doi.org/10.1016/j.epsl.2004.05.020, 2004.

Kromer, B., Lindauer, S., Synal, H. A., and Wacker, L.: MAMS A new AMS facility at the Curt-Engelhorn-Centre for Achaeometry, Mannheim, Germany, Nucl. Instrum. Meth. B, 294, 11-13, https://doi.org/10.1016/j.nimb.2012.01.015, 2013.

Lechleitner, F. A., Baldini, J. U. L., Breitenbach, S. F. M., Fohlmeister, J., Mcintyre, C., Goswami, B., Jamieson, R. A., van der Voort, T. S., Prufer, K., Marwan, N., Culleton, B. J., Kennett, D. J., Asmerom, Y., Polyak, V., and Eglinton, T. I.: Hydrological and climatological influences on a very high resolution tropical stalagmite radiocarbon record, Geochim. Cosmochim. Ac., 194, 233-252, https://doi.org/10.1016/j.gca.2016.08.039, 2016.

Lotsch, A., Friedl, M. A., Anderson, B. T., and Tucker, C. J.: Coupled vegetation-precipitation variability observed from satellite and climate records, Geophys. Res. Lett., 30, 14, https://doi.org/10.1029/2003GL017506, 2003.

Markowska, M., Fohlmeister, J., Treble, P. C., Baker, A., Andersen, M. S., and Hua, Q.: Modelling the ${ }^{14} \mathrm{C}$ bombpulse in young speleothems using a soil carbon continuum model, Geochim. Cosmochim. Ac., 261, 342-367, https://doi.org/10.1016/J.GCA.2019.04.029, 2019.

Mies, B. and Beyhl, F. E.: The vegetation ecology of Soqotra, in: Proceedings of the First International Symposium on Soqotra Island: Present and Future, Aden (March 1996), edited by: Dumont, H., Vol. 1, 35-82, United Nations Publications, Global Environment Facility, Conservation and Sustainable Use of Biodiversity of Soqotra Archipelago, Vol. 1, ISBN 90-804341-1-6, New York, NY, USA, 1998.

Myers, C. G., Oster, J. L., Sharp, W. D., Bennartz, R., Kelley, N. P., Covey, A. K., and Breitenbach, S. F. M.: Northeast Indian stalagmite records Pacific decadal climate change: Implications for moisture transport and drought in India, Geophys. Res. Lett., 42, 4124-4132, https://doi.org/10.1002/2015GL063826, 2015.

Noronha, A. L., Johnson, K. R., Hu, C., Ruan, J., Southon, J. R., and Ferguson, J. E.: Assessing influences on speleothem dead carbon variability over the Holocene: Implications for speleothembased radiocarbon calibration, Earth Planet. Sc. Lett., 394, 2029, https://doi.org/10.1016/j.eps1.2014.03.015, 2014.

Overpeck, J., Anderson, D., Trumbore, S., and Prell, W.: The southwest Indian Monsoon over the last 18000 years, Clim. Dynam., 12, 213-225, https://doi.org/10.1007/BF00211619, 1996.

Popov, G. B.: The vegetation of Socotra, Bot. J. Linn. Soc., 55, 706720, https://doi.org/10.1111/j.1095-8339.1957.tb00031.x, 2008.

Reimer, P. J., Bard, E., Bayliss, A., Beck, J. W., Blackwell, P. G., Bronk Ramsey, C., Buck, C. E., Cheng, H., Edwards, R. L., Friedrich, M., Grootes, P. M., Guilderson, T. P., Haflidason, H., Hajdas, I., Hatté, C., Heaton, T. J., Hoffmann, D. L., 
Hogg, A. G., Hughen, K. A., Kaiser, K. F., Kromer, B., Manning, S. W., Niu, M., Reimer, R. W., Richards, D. A., Scott, E. M., Southon, J. R., Staff, R. A., Turney, C. S. M., and van der Plicht, J.: IntCal13 and Marine13 Radiocarbon Age Calibration Curves 0-50 000 Years cal BP, Radiocarbon, 55, 1869-1887, https://doi.org/10.2458/azu_js_rc.55.16947, 2013.

Rudzka, D., McDermott, F., Baldini, L. M., Fleitmann, D., Moreno, A., and Stoll, H.: The coupled $\delta^{13}$ C-radiocarbon systematics of three Late Glacial/early Holocene speleothems; insights into soil and cave processes at climatic transitions, Geochim. Cosmochim. Ac., 75, 4321-4339, https://doi.org/10.1016/j.gca.2011.05.022, 2011.

Schaub, M., Büntgen, U., Kaiser, K. F., Kromer, B., Talamo, S., Andersen, K. K., and Rasmussen, S. O.: Lateglacial environmental variability from Swiss tree rings, Quaternary Sci. Rev., 27, 2941, https://doi.org/10.1016/j.quascirev.2007.01.017, 2008.

Schlüter, T.: Geological Atlas of Africa: with Notes on Stratigraphy, Tectonics, Economic Geology, Geohazard and Geosites of Each Country, Springer-Verlag, Berlin, Heidelberg, https://doi.org/10.1007/3-540-29145-8, 2006.

Scholte, P. and De Geest, P.: The climate of Socotra Island (Yemen): A first-time assessment of the timing of the monsoon wind reversal and its influence on precipitation and vegetation patterns, J. Arid Environ., 74, 1507-1515, https://doi.org/10.1016/j.jaridenv.2010.05.017, 2010.

Scholz, D. and Hoffmann, D. L.: StalAge - An algorithm designed for construction of speleothem age models, Quat. Geochronol., 6, 369-382, https://doi.org/10.1016/j.quageo.2011.02.002, 2011.

Schulz, H., van Rad, U., and Erlenkeuser, H.: Correlation between Arabian Sea and Greenland climate oscillations of the past 110000 years, Nature, 393, 54-57, https://doi.org/10.1038/31750, 1998.

Shakun, J. D., Burns, S. J., Fleitmann, D., Kramers, J., Matter, A., and Al-Subbary, A. A.: A high-resolution, absolute-dated deglacial speleothem record of Indian Ocean climate from Socotra Island, Yemen, Earth Planet. Sc. Lett., 259, 442-456, https://doi.org/10.1016/j.epsl.2007.05.004, 2007.

Soulet, G., Skinner, L. C., Beaupré, S. R., and Galy, V.: A note on reporting of reservoir ${ }^{14} \mathrm{C}$ disequilibria and age offsets, Radiocarbon, 58, 205-211, https://doi.org/10.1017/RDC.2015.22, 2016.

Southon, J., Noronha, A. L., Cheng, H., Edwards, R. L., and Wang, Y.: A high-resolution record of atmospheric ${ }^{14} \mathrm{C}$ based on Hulu Cave speleothem H82, Quaternary Sci. Rev., 33, 32-41, https://doi.org/10.1016/j.quascirev.2011.11.022, 2012.
Synal, H. A., Stocker, M., and Suter, M.: MICADAS: A new compact radiocarbon AMS system, Nucl. Instrum. Meth. B, 259, 713, https://doi.org/10.1016/j.nimb.2007.01.138, 2007.

Therre, S., Fohlmeister, J., Fleitmann, D., Matter, A., Burns, S. J., Arps, J., Schröder-Ritzrau, A., Friedrich, R., and Frank, N.: U-series and radiocarbon dating results of stalagmite M1-5 from Moomi Cave, Socotra Island, PANGAEA, https://doi.org/10.1594/PANGAEA.906003, 2019.

Treble, P. C., Fairchild, I. J., Baker, A., Meredith, K. T., Andersen, M. S., Salmon, S. U., Bradley, C., Wynn, P. M., Hankin, S. I., Wood, A., and McGuire, E.: Roles of forest bioproductivity, transpiration and fire in a nine-year record of cave dripwater chemistry from southwest Australia, Geochim. Cosmochim. Ac., 184, 132-150, https://doi.org/10.1016/j.gca.2016.04.017, 2016.

Trumbore, S.: Radiocarbon and Soil Carbon Dynamics, Annu. Rev. Earth Pl. Sc., 37, 47-66, https://doi.org/10.1146/annurev.earth.36.031207.124300, 2009.

Unkel, I.: AMS- ${ }^{14} \mathrm{C}$-Analysen zur Rekonstruktion der Landschaftsund Kulturgeschichte in der Region Palpa (S-Peru), Heidelberg University, 2006.

Warken, S. F., Fohlmeister, J., Schröder-Ritzrau, A., Constantin, S., Spötl, C., Gerdes, A., Esper, J., Frank, N., Arps, J., Terente, M., Riechelmann, D. F. C., Mangini, A., and Scholz, D.: Reconstruction of late Holocene autumn/winter precipitation variability in SW Romania from a high-resolution speleothem trace element record, Earth Planet. Sc. Lett., 499, 122-133, https://doi.org/10.1016/j.epsl.2018.07.027, 2018.

Wefing, A. M., Arps, J., Blaser, P., Wienberg, C., Hebbeln, D., and Frank, N.: High precision U-series dating of scleractinian cold-water corals using an automated chromatographic U and Th extraction, Chem. Geol., 475, 140-148, https://doi.org/10.1016/j.chemgeo.2017.10.036, 2017.

Zhou, J., Lundstrom, C. C., Fouke, B., Panno, S., Hackley, K., and Curry, B.: Geochemistry of speleothem records from southern Illinois: Development of $\left({ }^{234} U\right) /\left({ }^{238} U\right)$ as a proxy for paleoprecipitation, Chem. Geol., 221, 1-20, https://doi.org/10.1016/j.chemgeo.2005.02.005, 2005. 